\title{
EVALUATION OF NUTRIENTS STATUS OF SOILS UNDER RICE CULTIVATION IN CROSS RIVER STATE, NIGERIA
}

\author{
I. N. ONYEKWERE, A. G. IWO, A. O. ANO AND A. O. OSUNDE
}

(Received 13 June 2015; Revision Accepted 5 October 2015)

\begin{abstract}
Nutrients status of soils under rice cultivation in Cross River State Nigeria was evaluated to ascertain the present status and suggest management practices needed for an increased rice production. A reconnaissance survey of the entire State was undertaken. A total number of eight Local Government Areas, namely Odukpani, Biase, Yakkur, Abi, Obubura, Ogoja, Yala, and Bekwara were identified to have comparative advantage in rice production, which cut across the entire Agricultural zones of the state. A free survey method was adopted in sampling the soils at $0-15 \mathrm{~cm}$ depth in sixteen communities of the identified Local Government Areas. A total of 108 composite samples were collected and analyzed in laboratory. The results revealed that the soils had a mean $\mathrm{pH}$ value of 5.26, exchangeable $\mathrm{Ca}\left(4.98 \mathrm{cmol} \mathrm{kg}^{-1}\right)$, exchangeable $\mathrm{Mg}\left(1.40 \mathrm{cmol} \mathrm{kg}^{-1}\right)$, exchangeable $\mathrm{Na}\left(0.28 \mathrm{cmol} \mathrm{kg}{ }^{-1}\right)$, exchangeable $\mathrm{K}(0.07$ cmol kg-1), ECEC $\left(9.08 \mathrm{cmol} \mathrm{kg}^{-1}\right)$, organic carbon( $\left.0.98 \%\right)$, total $\mathrm{N}(0.07 \%)$, available $\mathrm{P}\left(17.64 \mathrm{mg} \mathrm{kg}^{-1}\right)$, available Fe $\left(898.33 \mathrm{mgkg}^{-1}\right)$, available $\mathrm{Zn}\left(3.05 \mathrm{mgkg}^{-1}\right)$ and available $\mathrm{Mn}\left(92.90 \mathrm{mgkg}^{-1}\right)$. For increased rice yield in the area some good management practices such as planting of iron tolerant rice varieties and application of deficient nutrient elements are recommended
\end{abstract}

KEYWORDS: Evaluation, Nutrient status, Soils, Cross River.

\section{INTRODUCTION}

Rice is one food crop that has solved or nearly solved the food problem of many densely populated countries like India, Japan, Taiwan and South Korea. Nigeria having serious food security problem that is gulping the country's hard earned foreign earnings through food importation especially rice can borrow a leaf from these nations, by developing her rice production culture (Onyekwere et. al., 2010). The first step in this direction is to identify suitable environment which the rice culture can be established.

(Adebisi et al 2008) reported that, this crop is an important staple food in Nigeria and indeed most countries in the world. Though in Nigeria, there has been a gradual increase in the production of the commodity over the past years, demand and consumption have also increased drastically. Oladiran, (2010) estimated that Nigeria imported about 22 billon $\mathrm{kg}$ of rice in 2010 to meet local requirements. Therefore, there is need to increase the local production of rice for us to meet its present demand in Nigeria

Declining soil fertility and inadequate and uneven distribution of rainfall are the major problems militating against increase in rice production in this country. For Nigeria to cope with the increase in the present demand and consumption of the commodity, Water availability and soil fertility must be tackled to enhance local production. The problem associated with rainfall could be solved through the use of irrigation while making sustainable research on effort towards improving soils fertility status for yield increase is necessary.

Therefore soil fertility decline could be alleviated through fertilizer application, for fertilizer application to be effective the type and quality of fertilizer must depend on soil test result, otherwise soil abuse and low yield may be the result. The objectives of this work were, to determine the nutrients status of soils of Cross River State, Nigeria under rice production and to determine management practices required for sustainable rice production on these soils.

\section{MATERIALS AND METHODS}

\section{Study area}

The study area was Cross River State, Nigeria which lies between latitude $5^{\circ} 32^{1}$ and $4^{\circ} 27^{1} \mathrm{~N}$ and longitude $7^{\circ} 15^{1}$ and $8^{\circ} 50^{1} \mathrm{E}$. The mean annual rainfall ranges from 1,700 to $4,000 \mathrm{~mm}$. The mean annual temperature is between 21 and $29^{\circ} \mathrm{C}$ and the vegetation is typical of the rainforest zone. The soils are derived from three major geological groups' namely recent alluvial deposit, tertiary coastal plain sand and the igneous and metamorphic rocks.

\section{Sampling scheme}

A reconnaissance survey of the entire state was first undertaken, to enable the identification of areas having comparative advantage in rice production and at the same time get familiarized with the environment. A total of eight Local Government Areas were identified. These

I. N. Onyekwere, Soil Science Laboratory NRCRI, Umudike, Abia State, Nigeria.

A. G. Iwo, Department of Crop Science, Faculty of Agriculture, University of Calabar, Calabar, Nigeria.

A. O. Ano, Soil Science Laboratory NRCRI, Umudike, Abia State, Nigeria.

A. O. Osunde, Department of Soil Science, School of Agric and Agric Technology, Federal University Technology, Minna, Nigeria. 
include Odukpani and Biase in Calabar Agricultural zone (Southern Senatorial zone), Yakkur, Abi and Obubra in Ikom Agricultural zone (Central Senatorial zone) and Ogoja, Yala and Bekwara in Ogoja Agricultural zone (Northern Senatorial Zone). A free survey method was adopted in sampling the soils from sixteen communities within the eight Local Government Areas. Soil samples were collected at $0-15 \mathrm{~cm}$ depth, using soil auger. A total of 108 composite samples were made, labeled and then transported to the Soil Science Laboratory of the National Root Crops Research Institute (NRCRI), Umudike, Abia State for physico-chemical analysis.

\section{Laboratory Analysis.}

All soil samples were air dried, crushed and sieved through a $2 \mathrm{~mm}$ mesh and re-sieved through a $0.5 \mathrm{~mm}$ mesh for organic carbon and total $\mathrm{N}$ prior to physico-chemical analysis. Particle size distribution was determined by the hydrometer method (Bouyocos, 1962). Soil $\mathrm{pH}$ was derived in 1:2.5 soil/water ratio using a glass electrode $\mathrm{pH}$ meter (Bates, 1954). Exchangeable cations ( $\mathrm{Ca}, \mathrm{Mg}, \mathrm{K}$ and $\mathrm{Na}$ ) in the soils were determined through extraction with neutral molar solution of ammonium acetate solution. Calcium and magnesium in the extracts were determined by EDTA titration, while sodium and potassium were determined by photometry (Black et. al., 1975).

Exchangeable acidity were determined by leaching soil samples with neutral molar solution $\mathrm{KCl}$ and the acidity estimated by titrating with $0.02 \mathrm{M} \mathrm{NaOH}$ solution using phenolphthalein as indicator (Mclian, 1965).

Organic carbon was determined by the potassium dichromate wet oxidation method of Walkley and Black (1934) method. Total Nitrogen was determined by the modified kjedahl method (Black et al., 1973). Available $P$ was determined by Bray -2 method (Bray and Kurtz, 1945). Effective cation exchange capacity was calculated as the sum of the exchangeable bases and acidity. Some micronutrients (Fe, Zn, and $\mathrm{Mn})$ in the soil were extracted with $0.1 \mathrm{~N} \mathrm{HCl}$ solution and the filtrates were read with Atomic Absorption Spectrometer at their respective resonance lines using standard calibration method.

\section{RESULTS AND DISCUSSION}

\section{Physical Properties}

The physical properties of the soils of the study area are as shown in Table 1

\section{Particle size distribution.}

Sand was the predominant particle size fraction in all the soils studied, with a range of $41.80-76.80 \%$ and a mean value of $58 \%$. This is typical of soils originating from coarse parent materials as reported by Federal Ministry of Agriculture and Natural Resources (1990). Silt particle size fraction ranged from $12.49-$ $43.40 \%$, followed by clay with a range of $10.80-30.00$ $\%$.

\section{Textural Classification}

The texture of the soils ranged from sandy loam to sandy clay loam, with sandy Loam dominating the study area, occupying over $56 \%$ of the entire locations, followed by sandy clay loam with $25 \%$. The textural classification of the soils studied was ideal for rice production, because they were characterized by good aeration and tillage (Onykwere et. al., 2010).

Table 1: Physical properties of the soils Cultivated with rice in Cross River State

\begin{tabular}{|c|c|c|c|c|c|}
\hline \multirow[t]{2}{*}{$\mathbf{S} / \mathbf{N}$} & \multirow[t]{2}{*}{ Location } & \multicolumn{3}{|c|}{ Particle size distribution } & \multirow{2}{*}{$\begin{array}{l}\text { Textura } \\
\text { class }\end{array}$} \\
\hline & & Sand (\%) & Silt (\%) & Clay (\%) & \\
\hline 1 & Ikot Okon1 & 47.80 & 30.40 & 21.80 & $\mathrm{SCL}$ \\
\hline 2 & Ikot Okon2 & 41.80 & 43.40 & 14.80 & Loam \\
\hline 3 & $\begin{array}{l}\text { Akim-Akim } \\
\text { BIASE }\end{array}$ & 69.80 & 15.40 & 14.80 & SL \\
\hline 4 & Adim & 49.50 & 36.40 & 14.50 & SL \\
\hline 5 & $\begin{array}{l}\text { Abini } \\
\text { YAKKUR }\end{array}$ & 65.80 & 19.40 & 14.80 & SL \\
\hline 6 & Ugep & 49.80 & 21.40 & 28.80 & SCL \\
\hline 7 & $\begin{array}{l}\text { Assiga } \\
\text { ABI }\end{array}$ & 77.30 & 12.40 & 10.30 & SL \\
\hline 8 & Itigidi & 50.11 & 19.89 & 30.00 & SCL \\
\hline 9 & $\begin{array}{l}\text { Adadama } \\
\text { OBUBURA }\end{array}$ & 49.30 & 25.10 & 25.60 & Loam \\
\hline 10 & Apiapum & 41.80 & 31.40 & 26.80 & Loam \\
\hline 11 & $\begin{array}{l}\text { Ofudua } \\
\text { OGOJA }\end{array}$ & 59.80 & 21.40 & 18.80 & $\mathrm{SCL}$ \\
\hline 12 & Bansara & 71.80 & 15.40 & 12.80 & SL \\
\hline 13 & $\begin{array}{l}\text { Nkum } \\
\text { YALA }\end{array}$ & 61.80 & 19.40 & 18.80 & $\mathrm{SL}$ \\
\hline 14 & $\begin{array}{l}\text { Okpoma } \\
\text { BEKWARA }\end{array}$ & 64.50 & 16.00 & 19.50 & SL \\
\hline 15 & Ugboro & 69.75 & 18.35 & 11.90 & SL \\
\hline \multirow[t]{2}{*}{16} & Abichiche & $\begin{array}{l}65.11 \\
418-718\end{array}$ & 17.33 & $\begin{array}{l}17.56 \\
10.80-30\end{array}$ & SL \\
\hline & Mean & 58.48 & 2268 & 1984 & \\
\hline
\end{tabular}




\section{Some selected chemical Properties}

The results of some chemical properties of the soils of the study areas are shown in Table 2.

\section{Soil Reaction:}

The soil reaction as expressed by $\mathrm{pH}\left(\mathrm{H}_{2} \mathrm{O}\right)$ was moderately acidic $(5.08-5.68)$ with a mean value of 5.26. Agronomically, the $\mathrm{pH}$ range of the soils is good for rice cultivation, as it can make room for the availability of both macro and micro nutrients as well enhancing the activities of soil micro organisms in the soils (Ano and Onyekwere, 2008).

\section{Organic Carbon}

The Organic carbon content of the soils studied ranged from low to moderate $(0.17-2.29 \%$. with a mean value of $0,98 \%$. Soils of Yakkur, Abi, Obubra, Ogoja, Yala and Bekwara had low organic carbon content, while those of Odukpani and Biase were moderately endowed. Maintenance of a satisfactory organic matter status in these soils is highly essential, Onyekwere and Ezenwa (2009) reported enhanced mineralization of most of the nitrogen and half of the phosphorous in the soils, if the rice fields were unfertilized

\section{Calcium}

The exchangeable calcium of the soils studied ranged from low to high $\left(2.00-16.00 \mathrm{cmolkg}^{-1}\right)$, with a mean value of $4.98 \mathrm{cmol} \mathrm{kg}^{-1}$. Soils of Akim-Akim (Odukpani), Biase, Bansara (Ogoja) and Ugoro (Bekwara) had values below $4 \mathrm{cmol} \mathrm{kg}^{-1}$ regarded as lower limit for fertile soils (Onyekwere et.al., 2001), while the soils from the remaining location had values above $4.0 \mathrm{cmol} \mathrm{kg}^{-1}$.

\section{Magnesium}

The exchangeable magnesium content of the soils studied varied from low to high $\left(0.40-2.82 \mathrm{cmol} \mathrm{kg}^{-1}\right)$ with a mean value of $1.40 \mathrm{cmol} \mathrm{kg}^{-1}$., the soils are well endowed with exchangeable magnesium apart from soils of Biase that had values below $0.5 \mathrm{cmol} \mathrm{kg}^{-1}$ regarded as the critical value needed in soils (Onyekwere et. al.,2003).

\section{Sodium}

The exchangeable sodium content of the soils ranged from low to medium $\left(0.15\right.$ to $\left.0.47 \mathrm{cmolkg}^{-1}\right)$, with a mean value of $0.28 \mathrm{cmolkg}^{-1}$. All the soils of Odupkani, Biase, Obubara, Ogoja, Yala and Bekwara Local Government Areas in conjunction with soils of Ugep (Yakkur) and Itigidi (Abi) had exchangeable $\mathrm{Na}$ above $0.2 \mathrm{cmolkg}^{-1}$ regarded as the critical value needed in soils (Amalu, 1997).

\section{Effective Cation Exchange Capacity (ECEC)}

The ECEC of the soils studied ranged from low to high $\left(5.82-20.81 \mathrm{cmolkg}^{-1}\right.$, with a mean value of 9.08 . cmolkg .Generally, soils of the studied areas had moderate ECEC values apart from soils of Biase and Ogoja that had low ECEC values while the soils of Ikot Okon 2 (Odukpani) had value above $20 \mathrm{cmol} \mathrm{kg}^{-1}$ regarded as being suitable for crop production if other factors are favourable (Onyekwere et.al., 2003), quoting FAO (1976). 


\begin{tabular}{|c|c|c|c|c|c|c|c|c|c|c|c|}
\hline \multirow[t]{2}{*}{$\begin{array}{l}\text { S/ } \\
\text { No }\end{array}$} & \multirow[t]{2}{*}{ Location } & \multirow[t]{2}{*}{$\begin{array}{l}\mathrm{pH} \\
\left(\mathrm{H}_{2} 0\right)\end{array}$} & \multirow[t]{2}{*}{$\mathrm{Ca}$} & \multirow{2}{*}{$\begin{array}{l}\text { Exchangeable } \\
\mathrm{Mg} \\
\longrightarrow\end{array}$} & \multirow{2}{*}{ 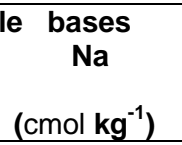 } & \multicolumn{2}{|c|}{$\begin{array}{l}\text { Exchangeable } \\
\mathrm{H}^{+}\end{array}$} & \multirow[t]{2}{*}{$\begin{array}{l}\text { Acidity } \\
\mathrm{Al}^{3+}\end{array}$} & \multirow[t]{2}{*}{ ECEC } & \multirow[t]{2}{*}{$\begin{array}{l}\text { BS } \\
(\%)\end{array}$} & \multirow[t]{2}{*}{$\begin{array}{l}\text { Org. C. } \\
(\%)\end{array}$} \\
\hline & & & & & & . & & & & & \\
\hline & ODUKPAN & 1 & & & & & & & & & \\
\hline 1 & Ikot Okon 1 & 5.58 & 6.80 & 0.40 & 0.25 & 2.24 & & 0.56 & 10.29 & 72.78 & 2.29 \\
\hline 2 & Ikot Okon 2 & 5.29 & 16.00 & 1.60 & 0.47 & 1.84 & & 0.24 & 20.31 & 89.73 & 1.71 \\
\hline 3 & $\begin{array}{l}\text { Akim-Akim } \\
\text { BIASE }\end{array}$ & 5.25 & 2.00 & 0.80 & 0.25 & 1.92 & & 0.80 & 5.82 & 53.26 & 1.71 \\
\hline 4 & ADIM & 5.13 & 3.20 & 0.80 & 0.26 & 1.84 & & 0.32 & 6.46 & 66.56 & 1.92 \\
\hline 5 & $\begin{array}{l}\text { Abini } \\
\text { YAKKUR }\end{array}$ & 5.68 & 2.40 & 0.80 & 0.25 & 1.60 & & 0.25 & 1.13 & 68.81 & 0.81 \\
\hline 6 & Ugep & 5.08 & 6.80 & 0.40 & 0.34 & 0.64 & & 0.96 & 9.24 & 82.68 & 0.64 \\
\hline 7 & $\begin{array}{l}\text { Assiga } \\
\mathrm{ABI}\end{array}$ & 5.38 & 4.40 & 1.60 & 1.15 & 0.96 & & 0.72 & 7.88 & 78.68 & 0.61 \\
\hline 8 & Itigidi & 5.25 & 5.40 & 2.82 & 0.29 & 1.11 & & 0.65 & 10.40 & 83.08 & 0.98 \\
\hline 9 & $\begin{array}{l}\text { Adadama } \\
\text { OBUBURA }\end{array}$ & 5.20 & 4.50 & 2.62 & 0.19 & 0.98 & & 0.69 & 9.07 & 81.59 & 0.81 \\
\hline 10 & Apiapum & 5.10 & 4.00 & 0.40 & 0.28 & 4.74 & & 1.84 & 11.45 & 42.70 & 0.17 \\
\hline 11 & $\begin{array}{l}\text { Ofudua } \\
\text { OGOJA }\end{array}$ & 5.41 & 4.40 & 2.80 & 0.30 & 3.04 & & 0.96 & 11.54 & 65.33 & 0.61 \\
\hline 12 & Bansara & 5.12 & 3.60 & 1.60 & 0.33 & 1.68 & & 0.44 & 7.23 & 76.76 & 0.27 \\
\hline 13 & $\begin{array}{l}\text { Nkum } \\
\text { YALA }\end{array}$ & 5.10 & 4.00 & 0.80 & 0.28 & 0.88 & & 0.80 & 6.80 & 75.29 & 0.71 \\
\hline 14 & $\begin{array}{l}\text { Okpoma } \\
\text { BEKWARA }\end{array}$ & 5.14 & 4.12 & 1.86 & 0.31 & 1.59 & & 0.06 & 7.79 & 82.40 & 0.75 \\
\hline 15 & Ugboro & 5.20 & 3.98 & 1.91 & 0.29 & 0.89 & & 0.80 & 7.92 & 78.66 & 0.85 \\
\hline \multirow[t]{3}{*}{16} & Abochiche & 5.18 & 4.10 & 1.12 & 0.28 & 1.42 & & 0.75 & 7.72 & 71.89 & 0.85 \\
\hline & Range & $\begin{array}{lll}5.10 & -5.68\end{array}$ & $2.00-16.00$ & $0.40-1.91$ & $0.15-0.47$ & 0.64 & -4.74 & $0.24-1.84$ & $1.13-20.31$ & $42.70-89.75$ & $0.17-2.29$ \\
\hline & Mean & 5.26 & 4.98 & 1.40 & 0.28 & 1.71 & & 0.63 & 9.08 & 73.14 & 0.98 \\
\hline
\end{tabular}




\section{Primary nutrients.}

$\mathrm{N}, \mathrm{P}$ and $\mathrm{K}$ are the primary nutrients most commonly demanded by crops in plant nutrition. This explains why most compound fertilizers and fertilizer requirements for the crop (rice) is based on N, P and $\mathrm{K}$ and their results are shown in Table 3

\section{Total $\mathbf{N}$.}

The results obtained showed that the total $\mathrm{N}$ of the soils studied ranged from low to moderate (0.04 to $0.25 \%)$ with a mean value of $0.07 \%$. The result of total $\mathrm{N}$ is a reflection of the organic carbon content of the soils (Onyekwere et. al., 2009). Soils of Odukpani local government area had moderate total $\mathrm{N}$ content, while the remaining soils had low total $\mathrm{N}$ content. Variable response of rice to applied nitrogen fertilizer is thus expected in these soils.
Available $P$.

Available phosphorous values of the soils ranged from low to very high $\left(9-54 \mathrm{mgkg}^{-1}\right) /$ with a mean of value of $17.64 \mathrm{mgkg}^{-1}$. Soils of Odukpani had very high available $P$ content, whereas available $P$ was very low in soils of Ogoja,Yala and Bekwara compared to others.

\section{Potassium.}

The exchangeable potassium content of the soils studied was low $\left(0.02-0.21 \mathrm{cmol} \mathrm{kg}^{-1}\right)$, with a mean value of $0.07 \mathrm{cmol} \mathrm{kg}^{-1}$. The soils of Apiapum (Obubra) had values that are slightly above $0.20 \mathrm{cmol} \mathrm{kg}^{-1}$ value regarded to be the critical exchangeable $\mathrm{K}$ for soils of Southeastern Nigeria agro ecological zone (FPDD, 1989). This suggested that all the soils will show substantial responses to applied potassium fertilizer

Table 3: Primary nutrients of the soils cultivated with rice in Cross River State

\begin{tabular}{|c|c|c|c|c|}
\hline S/No & Location & $\begin{array}{c}\text { Total N } \\
(\%)\end{array}$ & $\begin{array}{l}\text { Avail. P } \\
\left(\mathrm{mg} \mathrm{kg}^{-1}\right)\end{array}$ & $\begin{array}{l}\mathrm{K} \\
\left(\mathrm{coml} \mathrm{kg}{ }^{-1}\right)\end{array}$ \\
\hline & ODUKPANI & & & \\
\hline 1 & Ikot Okon1 & 0.25 & 26.00 & 0.04 \\
\hline 2 & Ikot Okon2 & 0.14 & 54.00 & 0.16 \\
\hline 3 & $\begin{array}{l}\text { Akim Akim } \\
\text { BIASE }\end{array}$ & 0.15 & 10.00 & 0.05 \\
\hline 4 & Adim & 0.15 & 14.00 & 0.04 \\
\hline 5 & $\begin{array}{l}\text { Abini } \\
\text { YAKKUR }\end{array}$ & 0.08 & 12.00 & 0.05 \\
\hline 6 & Ugep & 0.05 & 13.00 & 0.10 \\
\hline 7 & $\begin{array}{l}\text { Assiga } \\
\mathrm{ABI}\end{array}$ & 0.06 & 10.00 & 0.05 \\
\hline 8 & Itigidi & 0.12 & 12.00 & 0.13 \\
\hline 9 & $\begin{array}{l}\text { Adadama } \\
\text { OBUBURU }\end{array}$ & 0.09 & 13.00 & 0.09 \\
\hline 10 & Apiapum & 0.05 & 12.00 & 0.21 \\
\hline 11 & $\begin{array}{l}\text { Ofudua } \\
\text { OGOJA }\end{array}$ & 0.06 & 11.00 & 0.04 \\
\hline 12 & Bansara & 0.02 & 0.04 & 0.09 \\
\hline 13 & $\begin{array}{l}\text { Nkum } \\
\text { YALA }\end{array}$ & 0.04 & 0.08 & $0 . .15$ \\
\hline 14 & $\begin{array}{l}\text { Opkoma } \\
\text { BEKWARA }\end{array}$ & 0.03 & 0.06 & 0.14 \\
\hline 15 & Ugboro & 0.05 & 0.08 & 0.12 \\
\hline \multirow[t]{3}{*}{16} & Abochiche & 0.05 & 0.07 & 0.10 \\
\hline & Range & $0.02-0.16$ & 0.04 & $0.04-0.21$ \\
\hline & Mean & 0.07 & 17.64 & 0.07 \\
\hline
\end{tabular}

\section{Micronutrients.}

The data for the micronutrient levels of the soils studied are shown in Table 4.

\section{Available iron.}

The available iron content in the soils studied was very high, ranging from 297.00 to $2,277.00 \mathrm{mgkg}^{-1}$, with mean value of $898.33 \mathrm{mgkg}^{-1}$. All the soils in the study area had value of $\mathrm{Fe}^{2+}$ exceeding $50-100 \mathrm{mgkg}^{-1}$ considered as the range in which rice starts to show toxicity symptoms especially in soils with low fertility status (Vansvoort et. al., 1984). This gives an indication that iron toxicity might be a problem to rice production in these soils. Therefore it is advisable that iron tolerant rice varieties such as, should be planted in the entire study area.

\section{Available manganese}

The results of the available manganese content in the soils studied ranged from low to very high ( $3.00-226.3$ $\mathrm{mgkg}^{-1}$ ) with a mean value of $92.90 \mathrm{mgkg}^{-1}$, exceeding the threshold range of $10-25 \mathrm{mgkg}^{-1}$ of $\mathrm{Mn}$ toxicity in soil (Umar et. al., 2001). With the $\mathrm{pH}$ values of the soils ranging from 5.08 to $5.68, \mathrm{Mn}$ toxicity in the soils will not pose a problem to rice production in the study area (Ano and Onyekwere, 2008). 


\section{Available zinc}

The avaailable zinc content in the soils studied ranged from low to high $\left(0.80\right.$ to $\left.11.80 \mathrm{mgkg}^{-1}\right)$, with a mean value of $3.05 \mathrm{mgkg}^{-1}$. This gives the indication that the soils are well endowed with available $\mathrm{Zn}$ content since the mean value exceeded $2.0 \mathrm{mgkg}^{-1}$ the moderate value of available zinc required in tropical soils as reported by Kparmwang et. al. (2000).

Table 4: Available micro nutrients of the soils cultivated to rice in Cross River State

\begin{tabular}{|c|c|c|c|c|}
\hline S/No & Location & $\mathrm{Fe}$ & $\begin{array}{l}\mathrm{Zn} \\
\mathrm{mg} \mathrm{kg}^{-1}\end{array}$ & $\mathrm{Mn}$ \\
\hline & ODUPKANI & & & \\
\hline 1. & Ikot Okon 1 & 1162.30 & 4.80 & 226.30 \\
\hline 2 & Ikot Okon 2 & 807.30 & 11.80 & 27.60 \\
\hline 3 & $\begin{array}{l}\text { Akim-Akim } \\
\text { BIASE }\end{array}$ & 297.00 & 2.70 & 3.00 \\
\hline 4 & ADIM & 1334.90 & 0.80 & 157.70 \\
\hline 5 & $\begin{array}{l}\text { Abini } \\
\text { YAKKUR }\end{array}$ & 539.7 & 2.10 & 23.10 \\
\hline 6 & Ugep & 2277.20 & $4-30$ & 113.70 \\
\hline 7 & $\begin{array}{l}\text { Assiga } \\
\text { ABI }\end{array}$ & 404.10 & 1.40 & 72.50 \\
\hline 8 & Itigidi & 767.11 & 3.55 & 78.37 \\
\hline 9 & $\begin{array}{l}\text { Adadama } \\
\text { OBUBURU }\end{array}$ & 816.17 & 2.75 & 80.42 \\
\hline 10 & Apiapum & 1465.7 & 3.60 & 156.70 \\
\hline 11 & $\begin{array}{l}\text { Ofudua } \\
\text { OGOJA }\end{array}$ & 315.00 & 1.50 & 162.50 \\
\hline 12 & Bansara & 1010.40 & 0.90 & 149.60 \\
\hline 13 & $\begin{array}{l}\text { Nkum } \\
\text { YALA }\end{array}$ & 441.20 & 2.20 & 58.60 \\
\hline 14 & $\begin{array}{l}\text { Okpoma } \\
\text { BEKWARA }\end{array}$ & 976.30 & 1.71 & 72.11 \\
\hline 15 & Ugboro & 1009.11 & 2.70 & 48.61 \\
\hline \multirow[t]{2}{*}{16} & Abochiche & 849.75 & 1.95 & 55.63 \\
\hline & $\begin{array}{l}\text { Range } \\
\text { Mean }\end{array}$ & $\begin{array}{l}297-2277.2 \\
89833\end{array}$ & $\begin{array}{l}0,88- \\
305\end{array}$ & $\begin{array}{l}3-226.3 \\
9290\end{array}$ \\
\hline
\end{tabular}

\section{CONCLUSION}

The findings in this study gave the following indications:

That the textural classification and the soil reaction of the soils are ideal for rice production They can give room for the availability and uptake of both micro and macro nutrients.

That the soils are further characterized by low to moderate organic carbon, low to high exchangeable $\mathrm{Ca}$, $\mathrm{Mg}$ and $\mathrm{Na}$, low primary nutrients and high micro nutrients, specially iron, therefore iron toxicity might be a problem to rice production in the study area. Based on these finding, planting of iron tolerant rice varieties and application of $80 \mathrm{~kg} \mathrm{~N}, 40 \mathrm{Kg} \mathrm{P} \mathrm{P}_{2}$ and $40 \mathrm{Kg} \mathrm{K} 2 \mathrm{O}$ fertilizes are suggested for an increased rice yield in the area studied.

\section{REFERENCES}

Adebisi, M. A., Adeniyi, T. A., Ajala, M. O and Akintobi, D. C., 2008. Varietal differences in seed physiological quality of western African rice varieties after dry heat treatment. Nig. Agric. J., 39, (2): 159 -169.
Amalu, U. C., 1998. Evaluation of properties of selected soils of Cross-River Area and their management for increased cassava yields. Global Journal of Pure and Applied Sciences, 4, (3): 243-249.

Ano, A. O and Onyekwere, I. N., 2008. Soil and irrigation water report for identified areas suitable for rice production in Cross River State, Pp16.

Bates, R. G., 1954. Electrometric pH determination. John Willy and Sons Inc. New York. 54.

Black, C. A., Evans, D. D., White, I. I., Enamirange, E. E and Clark, F. E., 1973. Method of soil analysis. Part 2; Chemical and Microbiological Properties American Soc of Agronomy. Madison, Wisconsin. (9): 459.

Bougoucos, G. H., 1962. Hydrometer method for making particle size analysis of soils Agronomy Journal, (54): $564-565$.

Bray, R. H and Kurtz, L. T., 1945. Determination of total and available forms of phosphorus in soils. Soil Science (59): $39-45$. 
Federal Ministry of Agriculture and Natural Resources., 1990. Literature review on soil fertility investigation in Nigeria (in five volumes), 281.

Fertilizer Procurement Distribution Department (FPDD)., 1989. Ministry of Agriculture and Natural Resources, Literature on soil fertility investigation in Nigeria.

Food and Agricultural Organization., 1976. A frame work for Land evaluation, FAO Soils Bulletine 32, $\mathrm{FAO}$, Rome.

Kparmwang, T., Chude, V. O., Raji, B. A and Odunze, A. C., 2000. Extractable micro nutrients in some soil developed on sandstones and shales in the Benue valley Nigeria. Nig. Journal of Research, (1): $42-48$.

Mclean, E. O., 1965. Aluminium in methods of soil Analysis (Ed: C.A. Block). Agronomy, part 2 American Society of Agronomy Madison Wisconsin. (9): 978 - 998.

Onyekwere, I. N., Akpan - Idiok, A. U., Amalu, U. C.,

Asewalam, D. O and Eze, P. C., 2001. Constraints and opportunities in agricultural utilization of some wet land soils in AKwa Ibom State. In: Ojeniyi et. al., (eds). Management of wetland soil for Sustainable Agriculture and Environment, 139 149.

Onyekwere, I. N., Chukwu, G. O and Ano, A. O., 2009. Characteristics and Management of soils of Akamkpa Area, Cross River State Nigeria for increased Cocoyam yields. Nigerian Agric Journal, 40, (1): $271-278$.

Onyekwere I. N., 2009. Properties of some wetland soils of the Niger Delta, Nigeria Nigerian Journal of Soil Science, 19, (1): $143-145$.
Onyekwere, I. N., Ano, A .O., Ezenwa, M. I. S., Osunde,

A .O and Bala, A., 2003. Assessment of exchangeable acidity status and management of wetland soils of Cross River State in: Ojeniyi et al (eds)..Land degradation. Agricultural productivity and rural poverty environmental implications. $202-207$.

Onyekwere, I. N., Iwo, G. A., Eze, P. C., Korieocha, D. S and Nwokocha, C. C., 2010. Characteristics and management of fadama soils of Barikan Sale Niger State, Nigeria Grown to Rice Nigerian Agric. Journal, 41, (1): 102 -108.

Umar, A., Ezenwa, M. I. S., Osunde, A. O and Olaniyan, G. O., 2001. The micro nutrients status of soil of Musa inland valley agro ecosystem in Bida central. Nigeria in: Ojeniyi et. al., (eds). Management of wetland soils for sustainable agriculture and environment. $221-225$.

Van Mansvoort, M. E. F., Latin, R, S., Brink Man R. and Van Breeman, R., 1984. Toxicities of wetland rice soil in wetland soils: Charaterization, classification and utilization S.J. Banta (ed) IRRI Los Bannos. The Philippines, $123-134$.

Walkley, A and Black, I. A., 1934. An examination of Degtgareff method for determining soil organic matter and a proposed modification of the chronic acid extraction method, Soil Science, (37): $29-32$. 